\title{
COMPARATIVE STUDY BETWEEN KETAMINE AND PROPOFOL COMBINATION VERSUS PROPOFOL ALONE FOR SEDATION OF PATIENTS UNDERGOING UPPER GASTROINTESTINAL TRACT ENDOSCOPY
}

\author{
By
El-Sayed Ahmed El-Feqy, Ahmed Mahmoud Mohamed El-Garhey and Abd El-Azeim Maamon Dawoud* \\ Department of Anesthesiology and Intensive Care, Faculty of Medicine, Al-Azhar \\ University \\ *Corresponding author: Abd El-Azeim Maamon Dawoud, \\ E-mail: abdomaamon90@gmail.com
}

\begin{abstract}
Background: Upper gastrointestinal (GI) endoscopy can cause pain and anxiety to the patients which in turn lead to hemodynamic instability and impairment in the patient tolerance. Consequently, adequate sedation and analgesia are required in such procedure to maintain the optimal conditions for patient's relief and recovery.
\end{abstract}

Objective: This work aimed to determine whether the use of ketofol instead of propofol resulted in fewer adverse respiratory events requiring physician intervention when used for procedural sedation and analgesia.

Patients and Methods: After approval of the Medical Ethical Committee at Al-Azhar University Hospitals, and after patient written consents, 60 patients of American Society of Anesthesiologists (ASA) physical status I or II, scheduled for elective upper GI endoscopy under sedation were enrolled in this randomized, controlled, prospective, double-blind, clinical trial study. Patients were randomly assigned into two equal groups:

Group (I) received $0.5 \mathrm{mg} / \mathrm{kg}$ propofol i.v. Within a period of 30-40 seconds.

Group (II) received 50mg ketamine plus $0.5 \mathrm{mg} / \mathrm{kg}$ propofol in $10 \mathrm{ml}$ normal saline within a period of $30-40$ seconds.

Results: The dose of propofol was equal in both groups. Hypoventilation was significantly lower in the group (II), compared to the group (I).

No significant difference was reported between both groups regarding hypoxia, heart rate, adverse effects, and systolic blood pressure, recorded after the procedure and 25-minute after the onset of procedure. Systolic blood pressure was significantly higher in the group (II), compared to the group (I), throughout the 20 minutes following propofol induction .

Conclusion: Combination of propofol and ketamine used for procedural sedation and analgesia in upper GI endoscopy had higher safety than the propofol alone. Respiratory and hemodynamic stability were more noted in the ketofol group than the propofol-only group .

Key words: Ketamine, Propofol, Deep sedation, upper GI endoscopy. 


\section{INTRODUCTION}

Propofol is a commonly used anasthetic agent characterized by sedative, amnesic and anxiolytic effects, but no analgesic effect. It has an early-onset action with a single dose and a short halflife. So, it is characterized by rapid recovery (Shah et al., 2011).

Ketamine is a non-barbiturate anasthetic agent that binds to N-methyl DAspartate (NMDA) receptors, causing dissociative anesthesia. It has acceptable analgesic and sedative effects, with minimal cardiovascular risk (Ozgul et al., 2013).

This study was designed to determine whether the use of Ketofol, compared to propofol results in fewer adverse respiratory and hemodynamic events when used for procedural sedation and analgesia in upper GI endoscopy.

\section{PATIENTS AND METHODS}

After approval of the Medical Ethical Committee at Al-Azhar University Hospitals, and after patient written consents, 60 patients of American Society of Anesthesiologists (ASA) physical status I or II, scheduled for elective upper GI endoscopy under sedation were enrolled in this randomized, controlled, prospective, double-blind, clinical trial study from April 2019 to September 2019 after.

Preoperative preparation: Routine preoperative assessment was done for all patients on the day before operation including history, clinical examination and laboratory investigations .

Anesthetic technique: All patients were secured by peripheral intravenous line.
They received $4 \mathrm{ml} / \mathrm{kg} / \mathrm{h}$ Ringer Lactate solution, 2 liters of nasal $\mathrm{O} 2$ during the procedure, and $0.03 \mathrm{mg} / \mathrm{kg}$ midazolam IV as a premedication.

Group (I) received $0.5 \mathrm{mg} / \mathrm{kg}$ propofol i.v. In a period of 30-45 second. If patients did not achieve adequate sedation (Ramsey 4 on Ramsey sedation scale) after $2 \mathrm{~min}$, another dose of $0.5 \mathrm{mg} / \mathrm{kg}$ propofol was applied every $2 \mathrm{~min}$. The maximum dose of propofol was $2 \mathrm{mg} / \mathrm{kg}$.

Group (II) received $50 \mathrm{mg}$ ketamine plus $0.5 \mathrm{mg} / \mathrm{kg}$ propofol i.v. in $10 \mathrm{ml}$ normal saline combination in a period of 30-45 second. If patients did not achieve adequate sedation (Ramsey 4 on Ramsey sedation scale) after 2 min., the same dose of this combination every $2 \mathrm{~min}$. was given Pre defined maximum dose for ketamine-propofol was $2 \mathrm{mg} / \mathrm{kg}$.

The Ramsay sedation scale was widely used for assessment of the depth of anathesia. The depth of sedation was maintained at the level 6 of Ramsay sedation scale throughout the procedure (Dawson et al., 2010).

Recovery from sedation was evaluated every 5 minutes, following end of the procedure, using the Modified Aldrete Score (MAS). The MAS was the standard post-anathetic recovery scoring system. MAS $\geq 9$ was required before discharge from the recovery unit (Valasareddy et al., 2018).

Peripheral O2 saturation, respiratory rate (RR), blood pressure, heart rate (HR), ECG, and capnography were detected preoperatively and every five minutes during the procedure. 
Sample size was calculated using STATA version 11 programs, setting the type -1 error $(\alpha)$ at 0.05 and the power (1$\beta)$ at 0.8 . According to Tutal et al. (2016), the percentage of respiratory distress among the propofol group was 19.1\% compared to none among the ketofol group. Accordingly, 30 cases were required in each group.

Our primary outcome was the occurrence of respiratory events, such as hypoxia, (defined as SPO2 < 93\%), and hypoventilation (defined as RR $<8$ breath/min). The secondary outcomes included HR, BP, nausea, vomiting, aspiration, emergence delirium, and laryngospasm.

\section{Statistical analysis:}

Data were analyzed based on the t-test and the P-value, using the statistical software package SPSS for Window Version 20.0. Quantitative data were expressed as medians (ranges), means \pm standard deviation (SD), whilst qualitative data were expressed as frequency and percentage. The Chi-square (X2) test was used to compare the incidence of two qualitative parameters. All data were statistically compared at the two-sided 5\% level of significance. P-value $<0.05$ was considered significant.

\section{RESULTS}

Sixty patients were eligible for our procedure. They were randomized into either the ketofol group or the propofolonly group, 30 patients for each. No statistically significant difference was found between the the two groups, regarding the patients demographic characteristics (Table 1).

Table (1) : Demographic characteristics of the study groups

\begin{tabular}{|c|c|c|c|}
\hline $\begin{array}{ll} & \text { Groups } \\
\end{array}$ & $\begin{array}{c}\text { Group ( I ) } \\
(\mathbf{n}=\mathbf{3 0})\end{array}$ & $\begin{array}{c}\text { Group ( II ) } \\
(n=30)\end{array}$ & p-value \\
\hline $\begin{array}{l}\text { Age (years) } \\
\text { Range } \\
\text { Mean } \pm \text { SD }\end{array}$ & $\begin{array}{c}35-61 \\
48.39 \pm 13.18\end{array}$ & $\begin{array}{c}38-62 \\
50.28 \pm 12.07\end{array}$ & $>0.05$ \\
\hline $\begin{array}{l}\text { Sex } \\
\text { Male } \\
\text { Female }\end{array}$ & $\begin{array}{l}17(56.7 \%) \\
13(43.3 \%)\end{array}$ & $\begin{array}{l}14(46.7 \%) \\
16(53.3 \%)\end{array}$ & $>0.05$ \\
\hline $\begin{array}{l}\text { Height }(\mathbf{c m}) \\
\text { Range } \\
\text { Mean } \pm \text { SD }\end{array}$ & $\begin{array}{c}155-172 \\
171.28 \pm 9.29\end{array}$ & $\begin{array}{c}153-176 \\
170.26 \pm 11.36\end{array}$ & $>0.05$ \\
\hline $\begin{array}{l}\text { Weight (kg) } \\
\text { Range } \\
\text { Mean } \pm \text { SD }\end{array}$ & $\begin{array}{c}54-82 \\
70.16 \pm 13.42\end{array}$ & $\begin{array}{c}54-83 \\
69.14 \pm 15.48\end{array}$ & $>0.05$ \\
\hline $\begin{array}{l}\text { ASA } \\
\text { I } \\
\text { II }\end{array}$ & $\begin{array}{l}13(43.3 \%) \\
17(56.7 \%)\end{array}$ & $\begin{array}{l}12(40.0 \%) \\
18(60.0 \%)\end{array}$ & $>0.05$ \\
\hline
\end{tabular}


Hypoxia and hypoventilation were demonstrated and compared between both groups. Patients group I showed higher frequency of hypoxia, compared to the group II , 5 cases $(16.7 \%)$, 1 case $(3.3 \%)$ respectively ( $\mathrm{P}>0.05)$. Three cases $(10.0 \%)$ in group II, and 13 cases $(43.3 \%)$ in group I had hypoventilation, which was statistically significant (Table 2).

Table (2): Comparison between groups regarding side effects and respiratory events

\begin{tabular}{|l|c|c|c|}
\hline Side effects $\quad$ Groups & $\begin{array}{c}\text { Group ( I ) } \\
(\mathbf{n = 3 0})\end{array}$ & $\begin{array}{c}\text { Group ( II ) } \\
(\mathbf{n = 3 0})\end{array}$ & p-value \\
\hline Hypoxia & $5(16.7 \%)$ & $1(3.3 \%)$ & 0.05 \\
\hline Hypoventilation & $13(43.3 \%)$ & $3(10.0 \%)$ & $<0.004^{* *}$ \\
\hline
\end{tabular}

Regarding oxygen saturation, our results showed a highly statistically significant difference between groups at 5 ,
10 and 20 minutes following induction. At 25 min, group II was not significantly different from group I (Table 3).

\section{Table (3): Comparison between groups according to SPO2}

\begin{tabular}{|l|c|c|c|}
\hline SPO2 (mmHg) & $\begin{array}{c}\text { Group ( I ) } \\
(\mathbf{n = 3 0})\end{array}$ & $\begin{array}{c}\text { Group ( II ) } \\
(\mathbf{n = 3 0})\end{array}$ & p-value \\
\hline Preoperative & $97.38 \pm 2.32$ & $97.88 \pm 1.61$ & $>0.05$ \\
\hline After 5 min & $95.06 \pm 3.12$ & $98.28 \pm 1.91$ & $<0.001^{* *}$ \\
\hline After 10 min & $93.95 \pm 2.72$ & $97.58 \pm 2.32$ & $<0.001^{* *}$ \\
\hline After 15 min & $95.36 \pm 2.92$ & $95.77 \pm 2.11$ & $>0.05$ \\
\hline After 20 min & $95.87 \pm 2.62$ & $97.78 \pm 1.51$ & $0.001^{* *}$ \\
\hline After 25 min & $97.07 \pm 1.81$ & $97.78 \pm 1.61$ & $>0.05$ \\
\hline Postoperative & $98.48 \pm 1.71$ & $98.79 \pm 2.52$ & $>0.05$ \\
\hline
\end{tabular}

Our results showed that group II had higher cardiovascular stability than group I. Regarding the systolic blood pressure (SBP), there was a statistically significant difference between both groups at 5, 10,
15, and 20 minutes following induction. At $25 \mathrm{~min}$, the II group was not significantly different from the group I (Table 4). 
Table (4): Comparison between groups according to SBP

\begin{tabular}{|c|c|c|c|}
\hline $\begin{array}{ll}\text { SBP (mmHg) } & \text { Groups } \\
\end{array}$ & $\begin{array}{c}\text { Group ( I ) } \\
(\mathbf{n}=30)\end{array}$ & $\begin{array}{c}\text { Group ( II ) } \\
(\mathbf{n}=30)\end{array}$ & p-value \\
\hline $\begin{array}{l}\text { Preoperative } \\
\text { Mean } \pm \text { SD }\end{array}$ & $\begin{array}{c}0(0 \%) \\
133.95 \pm 14.80\end{array}$ & $\begin{array}{c}0(0 \%) \\
133.54 \pm 15.01\end{array}$ & $>0.05$ \\
\hline $\begin{array}{l}\text { After } 5 \text { min } \\
\text { Mean } \pm \text { SD }\end{array}$ & $\begin{array}{c}5(17 \%) \\
99.07 \pm 13.28\end{array}$ & $\begin{array}{c}0(0 \%) \\
128.88 \pm 13.18\end{array}$ & $<0.001 * *$ \\
\hline $\begin{array}{l}\text { After } 10 \mathrm{~min} \\
\text { Mean } \pm \text { SD }\end{array}$ & $\begin{array}{c}10(33 \%) \\
100.18 \pm 15.21\end{array}$ & $\begin{array}{c}2(7 \%) \\
126.85 \pm 15.41\end{array}$ & $<0.001^{* * *}$ \\
\hline $\begin{array}{l}\text { After } 15 \text { min } \\
\text { Mean } \pm \text { SD }\end{array}$ & $\begin{array}{c}6(20 \%) \\
106.57 \pm 13.18 \\
\end{array}$ & $\begin{array}{c}2(7 \%) \\
127.87 \pm 13.08 \\
\end{array}$ & $0.003 *$ \\
\hline $\begin{array}{l}\text { After } 20 \mathrm{~min} \\
\text { Mean } \pm \text { SD }\end{array}$ & $\begin{array}{c}4(13 \%) \\
111.64 \pm 12.17\end{array}$ & $\begin{array}{c}0(0 \%) \\
129.89 \pm 12.27\end{array}$ & $0.018^{*}$ \\
\hline $\begin{array}{l}\text { After } 25 \text { min } \\
\text { Mean } \pm \text { SD }\end{array}$ & $\begin{array}{c}0(0 \%) \\
124.82 \pm 16.22\end{array}$ & $\begin{array}{c}0(0 \%) \\
126.85 \pm 16.43\end{array}$ & $>0.05$ \\
\hline $\begin{array}{l}\text { Postoperative } \\
\text { Mean } \pm \text { SD }\end{array}$ & $\begin{array}{c}0(0 \%) \\
126.65 \pm 14.20\end{array}$ & $\begin{array}{c}0(0 \%) \\
128.88 \pm 14.09\end{array}$ & $>0.05$ \\
\hline
\end{tabular}

As regared heart rate, there was no statistically significant difference between groups (Table 5).

Table (5): Comparison between groups according to heart rate

\begin{tabular}{|l|c|c|c|}
\hline $\begin{array}{l}\text { Heart rate } \\
\text { (beat/min) }\end{array}$ & $\begin{array}{c}\text { Group ( I ) } \\
(\mathbf{n = 3 0 )}\end{array}$ & $\begin{array}{c}\text { Group ( II ) } \\
(\mathbf{n = 3 0})\end{array}$ & p-value \\
\hline Preoperative & $84.09 \pm 15.13$ & $83.15 \pm 13.89$ & $>0.05$ \\
\hline After 5min. & $80.34 \pm 11.62$ & $81.34 \pm 12.69$ & $>0.05$ \\
\hline After 10min. & $78.31 \pm 11.96$ & $79.48 \pm 11.49$ & $>0.05$ \\
\hline After 15min. & $77.88 \pm 11.25$ & $77.11 \pm 11.09$ & $>0.05$ \\
\hline After 20 min. & $76.46 \pm 13.62$ & $79.64 \pm 9.98$ & $>0.05$ \\
\hline After 25min. & $81.94 \pm 4.93$ & $81.03 \pm 6.50$ & $>0.05$ \\
\hline Postoperative & $78.01 \pm 9.95$ & $82.50 \pm 8.61$ & $>0.05$ \\
\hline
\end{tabular}

Regarding the side effects, group II of nausea, vomiting, aspiration, showed no statistically significant emergence delirium and laryngeal spasm difference, compared to group I in terms (Table 6).

Table (6): Comparison between groups according to side effects.

\begin{tabular}{|c|c|c|c|}
\hline $\begin{array}{ll}\text { Side effects } & \text { Groups } \\
\end{array}$ & $\begin{array}{c}\text { Group ( I ) } \\
(\mathbf{n}=\mathbf{3 0})\end{array}$ & $\begin{array}{c}\text { Group ( II ) } \\
(\mathbf{n}=\mathbf{3 0})\end{array}$ & p-value \\
\hline Hypotension & $9(30.0 \%)$ & $2(6.7 \%)$ & $<0.02 *$ \\
\hline $\mathrm{N} \& \mathrm{~V}$ & $1(3.3 \%)$ & $1(3.3 \%)$ & 0.05 \\
\hline Delirium & $1(3.3 \%)$ & $2(6.7 \%)$ & 0.05 \\
\hline Laryngeal spasm & $2(6.7 \%)$ & $3(10.0 \%)$ & 0.05 \\
\hline Aspiration & $0(0.0 \%)$ & $0(0.0 \%)$ & 0.05 \\
\hline
\end{tabular}




\section{DISCUSSION}

This study highlighted the safety of adding ketamine to propofol for procedural sedation and analgesia in upper GI endoscopy. Ketamine is N-methyl-Daspartate receptor antagonist, which is primarily used as a hypnotic with analgesic effects. Indeed, it has minimal respiratory side effects, compared to other hypnotics like propofol. Importantly, it preserves the heart rate and the blood pressure, which is attributable to its protective sympathomimetic activity (Peltoniemi et al., 2016). Nevertheless, high doses might cause hallucination, visual problems, nausea, vomiting and laryngospasm (Tutal et al., 2016). Propofol is a commonly used sedative agent because of its short half-life, amnestic, anxiolytic, and antiemetic properties. Nevertheless, serious side effects may limit its spread such as respiratory depression, and hypotension. Hypotension is attributed to decreased cardiac output, and peripheral vascular resistance (Tutal et al., 2016). Indeed, propofol is combined to ketamine, in an attempt to reduce these side effects. The combination of propofol and ketamine has been efficiently used, either separate or in the same syringe, in variety of settings, including coronary artery surgery in adults, interventional radiology, sedation for spinal anesthesia, gynecological and ophthalmological procedures (Aydogan et al., 2013).

Hypoventilation was significantly more frequent in the propofol-only group, compared to the ketofol group (43.3\% vs $10.0 \%$ respectively). Our results agreed with Tandon et al. (2014) who compared ketofol to propofol in upper GIT endoscopy and showed that airway assistance was used in $15 \%$ in the propofol group compared to $3 \%$ in the ketofol group. Nevertheless, the study done by Ferguson et al. (2016), comparing the two drugs showed close results between the two groups. Hypoventilation was noted in $9 \%$ with ketofol and 4\% with propofol, and respiratory interventions in $14 \%$ with ketofol and $16 \%$ with propofol. This discrepancy may be attributable to the different applied procedures and the confounding effect of opioids.

According to hypoxia, no statistically significant difference was found between both groups. This result agreed with Ferguson et al. (2016) with occurence of hypoxia in $8 \%$ of patients with propofol, and $6 \%$ of patients with ketofol. Aspiration did not occur is any patient with both groups.

Our study showed that using propofol alone led to significant decrease in blood pressure as hypotension occurred in $30 \%$ of the patients, but the addition of ketamine to propofol has aborted the hemodynamic instability that occurred with propofol alone as hypotension occurred in $6.7 \%$ of the patients with ketofol. Propofol decreases systemic vascular resistance, cardiac contractility, and the preload, which all cause a decrease in arterial blood pressure. Propofol also inhibits arterial baroreflex and hypotension induced tachycardia (Stayer et al., 2010). There are some previous studies that reported propofolketamine combination is safe in means of hemodynamic stability in groups of 
pediatrics, emergency room, and regional analgesia patients (Tutal et al., 2016).

Smischney et al. (2012) compared ketamine-propofol and propofol in general anesthesia induction and reported lower myocardial depression and vasodilation in the ketaminepropofol group.

Providers have typically been reluctant to use ketamine in adults because of concern about emergence phenomena, with rates of $10 \%$ to $20 \%$ being quoted in the literature (Ferguson et al., 2016). The rates of unpleasant emergence delirium in our study were lower suggesting that in this regimen, one of the adverse events most likely to deter providers from the use of ketamine is less likely to occur with ketofol than when ketamine is used as a single agent. A previous randomized controlled trial by Perumal et al. (2015) who used ketamine with and without midazolam for emergency department sedation in adults showed a similar reduction in emergence phenomena when midazolam was combined with ketamine in adults.

\section{CONCLUSION}

Ketofol was a good choice for safe and effective sedation and analgesia in patients undergoing upper GI endoscopy. It resulted in less adverse respiratory events and a better hemodynamic stability. The frequency of postoperative nausea, vomiting and delirium were comparable in both groups.

\section{CONFLICTS OF INTEREST}

There were no conflicts of interest regarding the present study.

\section{REFERENCES}

1. Aydogan, H., Aydogan, T., Uyanikoglu, A., Kucuk, A., Yuce, H., Karahan, A. and Yalcin, S. (2013): Propofol-ketamine combination has shorter recovery times with similar hemodynamics compared to propofol alone in upper gastrointestinal endo-scopy in adults. A randomized trial. Acta Medica, 29: $77-82$

2. Dawson, R., von Fintel, N. and Nairn, S. (2010): Sedation assessment using the Ramsay scale. Emergency Nurse, 18(3): 1820.

3. Ferguson, I., Bell, A., Treston, G., New, L., Ding, M. and Holdgate, A. (2016): Propofol or ketofol for procedural sedation and analgesia in emergency medicine the POKER studies: a randomized double-blind clinical trial. Annals of Emergency Medicine, 68(5): 574-582.

4. Ozgul, U., Begec, Z., Karahan, K., Erdogan, M. A., Aydogan, M. S., Colak, C. and Ersoy, M. O. (2013): Comparison of propofol and ketamine-propofol mixture (Ketofol) on laryngeal tube-suction II conditions and hemodynamics: a randomized, prospective, double-blind trial. Current Therapeutic Research, 75: 39-43.

5. Peltoniemi, M. A., Hagelberg, N. M., Olkkola, K. T. and Saari, T. I. (2016): Ketamine: a review of clinical pharmacokinetics and pharmacodynamics in anesthesia and pain therapy. Clinical Pharmacokinetics, 55(9): 1059-1077.

6. Perumal, D., Adhimoolam, M., Selvaraj, N., Lazarus, S. and Mohammed, $M$. (2015): Midazolam premedication for ketamine-induced emergence phenomenon: a prospective observational study." Journal of Research in Pharmacy Practice, 4(2 ):89-93.

7. Shah, A., Mosdossy, G., McLeod, S., Lehnhardt, K., Peddle, M. and Rieder, $M$. (2011): A blinded, randomized controlled trial to evaluate ketamine/propofol versus 
ketamine alone for procedural sedation in children. Annals of Emergency Medicine, 57(5): 425-433.

8. Smischney, N., Beach, M. L., Loftus, R. W., Dodds, T. M. and Koff, M. D. (2012): Ketamine/propofol admixture (ketofol) is associated with improved hemodynamics as an induction agent: a randomized, controlled trial. Journal of Trauma and Acute Care Surgery, 73(1): 94-101.

9. Stayer, Stephen A. and Yang Liu. (2010): Pulmonary hypertension of the newborn. Best practice and research Clinical anaesthesiology, 24 (3): 375-386.

10. Tandon M, Pandey VK, Dubey GK, Pandey, C. and Wadhwa, N. (2014): Addition of sub anaesthetic dose of ketamine reduces gag reflex during propofol based sedation for upper gastrointestinal endoscopy: a prospective randomised doubleblind study. J Anaesth., 58(4):436-441.

11. Tutal, Z. B., Gulec, H., Derel?, N., Babayg.t, M., Kurtay, A., Inceoz, H. and Horasanl?, E. (2016): Propofol-ketamine combination: a choice with less complications and better hemodynamic stability compared to propofol? On a prospective study in a group of colonoscopy patients. Irish Journal of Medical Science , 185(3) : 699-704.

12. Valasareddy, K., Titu, G., Anil, R., Segaran, K., George, K. and Ranjan, R. (2018): Recovery Profile Using Modified Aldrete Score in Post Anaesthesia Care Unit After Sevoflurane or Desflurane Anaesthesia: A Prospective Randomised Study. Journal of Clinical and Diagnostic Research, 12(9) : 1-4. 


\section{در اسة مقارنة بين عقاري الكيتامين و البروبوفول و عقار

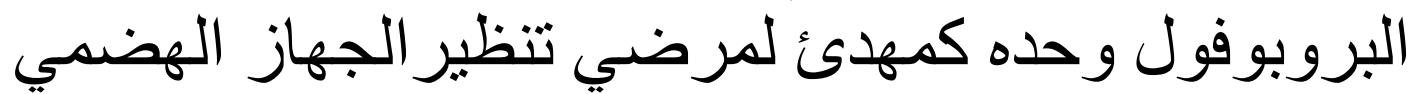 العلوي}

\section{السيا أحمد الفقي، أحمد محمود الجارحي، عبد العظيم مأمون داوود}

قسم التخدير والرعاية المركزة، كلية الطب، جامعة الازهر

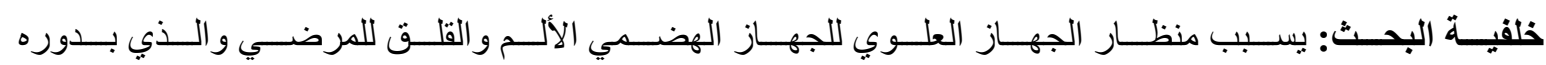

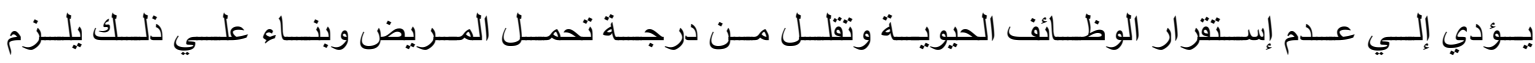

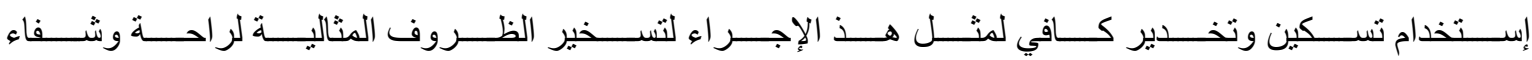
المرضي.

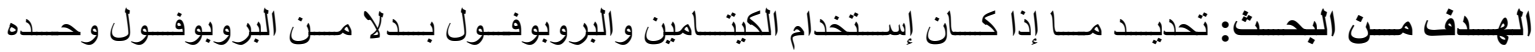

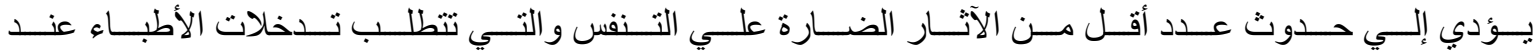
إستخدامها للتخدير الإجرائي وتسكين الألم في منظار الجهاز الهضمي العلوي.

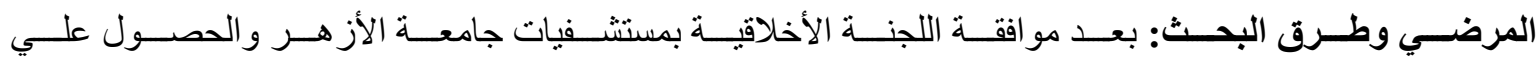

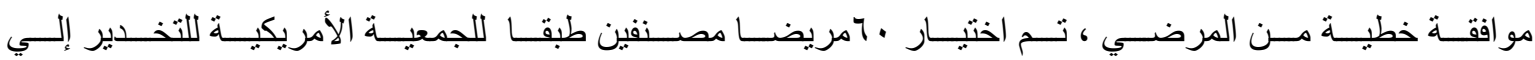

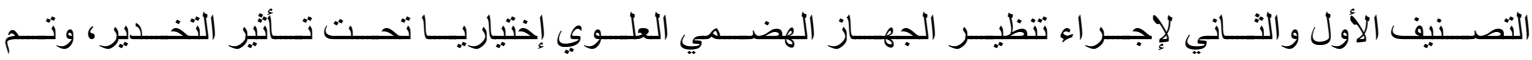
تقسيم المرضي عشو ائيا إلي مجمو عتين متساويتين. لإحسن.

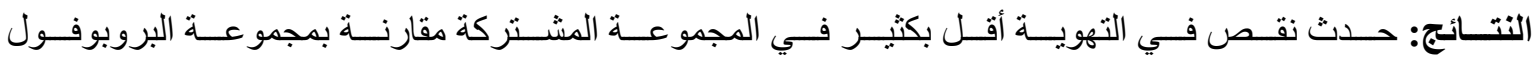

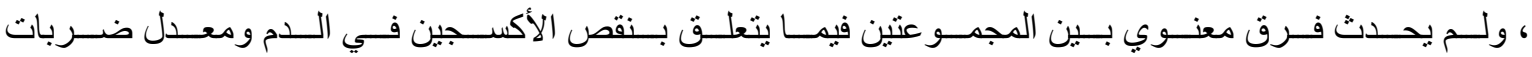

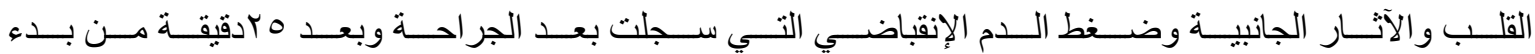

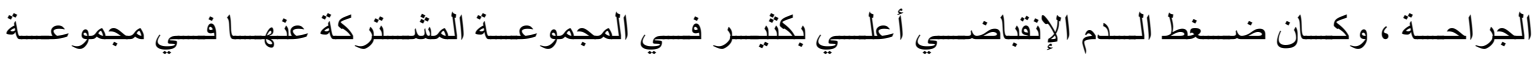
البروبوفول وخلال • r دقيقة بعد تحفيز البروبوفول.

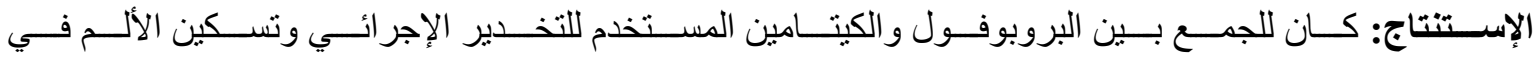

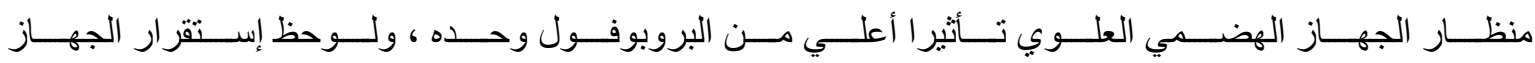
التنفسي والدورة الدموية في المجمو عة المشتركة أكثر من مجمو عة البروبوفول. 